\title{
Northeast Thailand before Angkor: Evidence from an Archaeological Excavation at the Prasat Hin Phimai
}

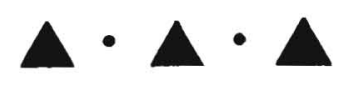

SARAH TALBOT AND CHUTIMA JANTHED

Almost A THOUSAND yeARS AGO, the walled city of Phimai (ancient Vimayapura) (Siribhadra and Moore 1997:232) was a major center of the polity of Angkor, which dominated much of mainland Southeast Asia from the ninth to the fifteenth centuries A.D. The Khmer empire is best known for the vast temple complex of Angkor Wat in the Tonle Sap region of Cambodia, although it also left a rich legacy of similar temples throughout Cambodia, Laos, and Thailand (Aymonier 1901; Briggs 1951; Freeman 1996; Siribhadra and Moore 1997).

An extensive network of roads and resthouses linked the provincial centers and temples. One such road covered the $225 \mathrm{~km}$ from Angkor Wat to the most important Khmer temple in Thailand, the Prasat Hin Phimai (Figs. 1, 2). Construction of the Prasat began during the reign of the Angkorian king Jayavarman VI (A.D. 1080-1107), whose family had ruled for several generations at Mahidharapura, perhaps Phimai itself (Jacques 1996:147; Pichard 1976:1). The name Mahidharapura has been given to the subsequent dynasty of Khmer kings, which included Suryavarman II (A.D. 1113-1150), responsible for the construction of Angkor Wat, and Jayavarman VII (A.D. 1181-1219), the last great king of Angkor, whose image can still be seen at Phimai today.

Khmer overlords had in fact shown interest in the region since the sixth century A.D. Several inscriptions refer to Citrasena-Mahendravarman's (c. A.D. 550-611) military victories beyond the Dang Raek Range, including one found at Phimai itself (K.1106) (Higham and Thosarat 1998:194; Jacques 1989:17; Vickery 1998 :75). However, while the consecration of Jayavarman II as monarch in A.D. 802 marked the start of the Angkorian period, it was not until some two centuries later that the region north of the Dang Raek Range was integrated into Angkor. From the reign of Rajendravarman II (A.D. 944-968) some control began to be exerted in the northeast (Siribhadra and Moore 1997:31), but most Khmer temples in Thailand were built after A.D. 1000. Although Jayavarman VII (A.D. 1181-1219) constructed the network of roads, resthouses, and hospitals that

Sarah Talbot is with the Anthropology Department, University of Otago, Dunedin, New Zealand, and Chutima Janthed is with the Royal Thai Fine Arts Department, Phimai, Thailand.

Asian Perspectives, Vol. 40, No. 2 (c) 2002 by University of Hawai'j Press. 


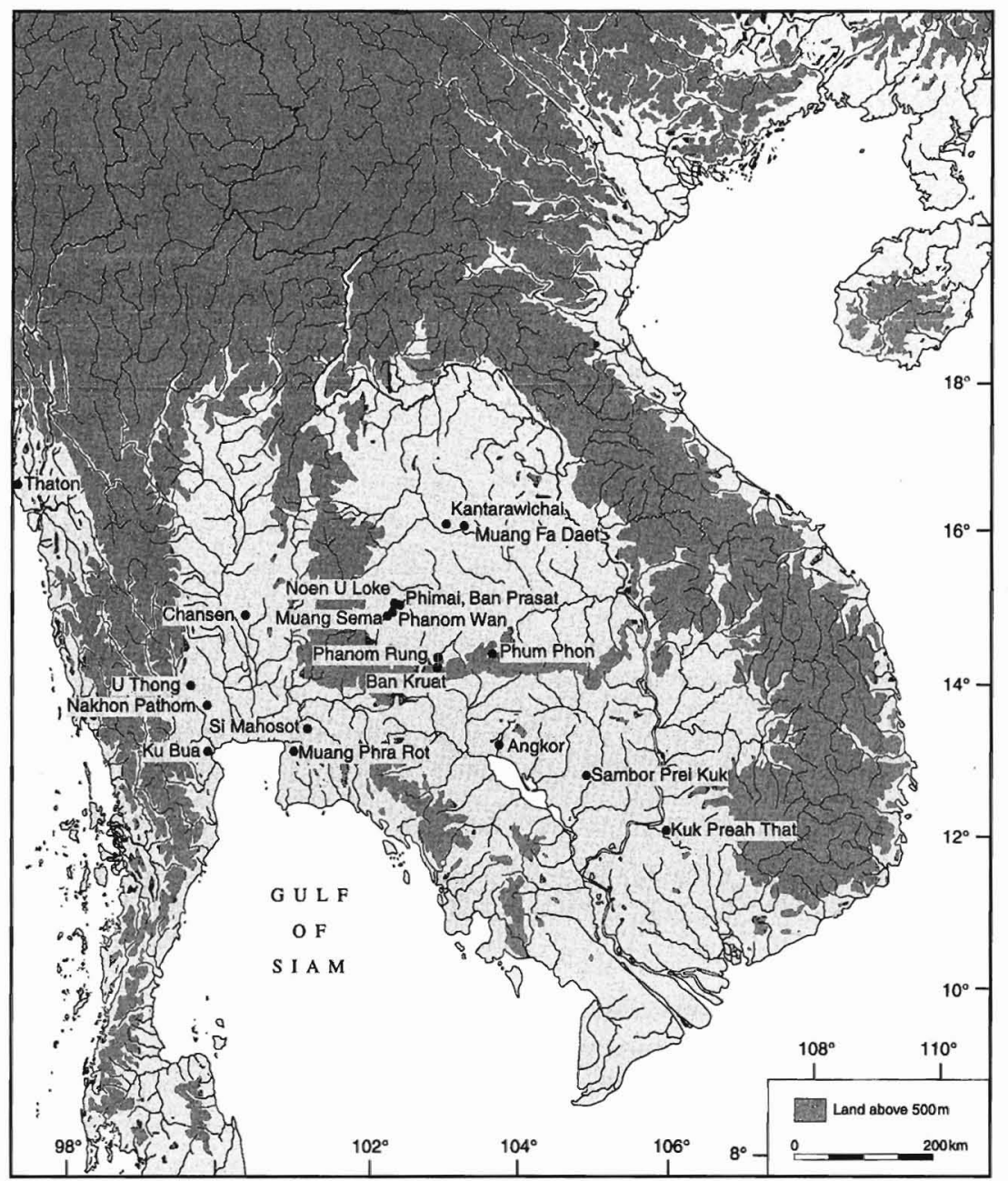

Fig. 1. Sites discussed in the text.

linked provincial centers to Angkor, his death saw the empire fragment. Prayers were offered at the Prasat Hin Phimai upon the death of Indravarman III in A.D. 1243 (Briggs 1951:238), but the late thirteenth century effectively saw the end of the Angkorian control in what is now northeast Thailand.

\section{NORTHEAST THAILAND BEFORE ANGKOR}

Northeast Thailand in the centuries immediately prior to Angkor has traditionally been described as lacking social complexity and subject to influences from two competing kingdoms-Dvaravati, a Mon-Buddhist culture in central Thailand, and Chenla, a Khmer-Hindu culture in the Kompong Thon region of Cambodia (see, for example, Quaritch Wales 1969). The very nature of the ostensible Dvaravati and Chenla "kingdoms" have more recently been reconsidered (Brown 1996; 


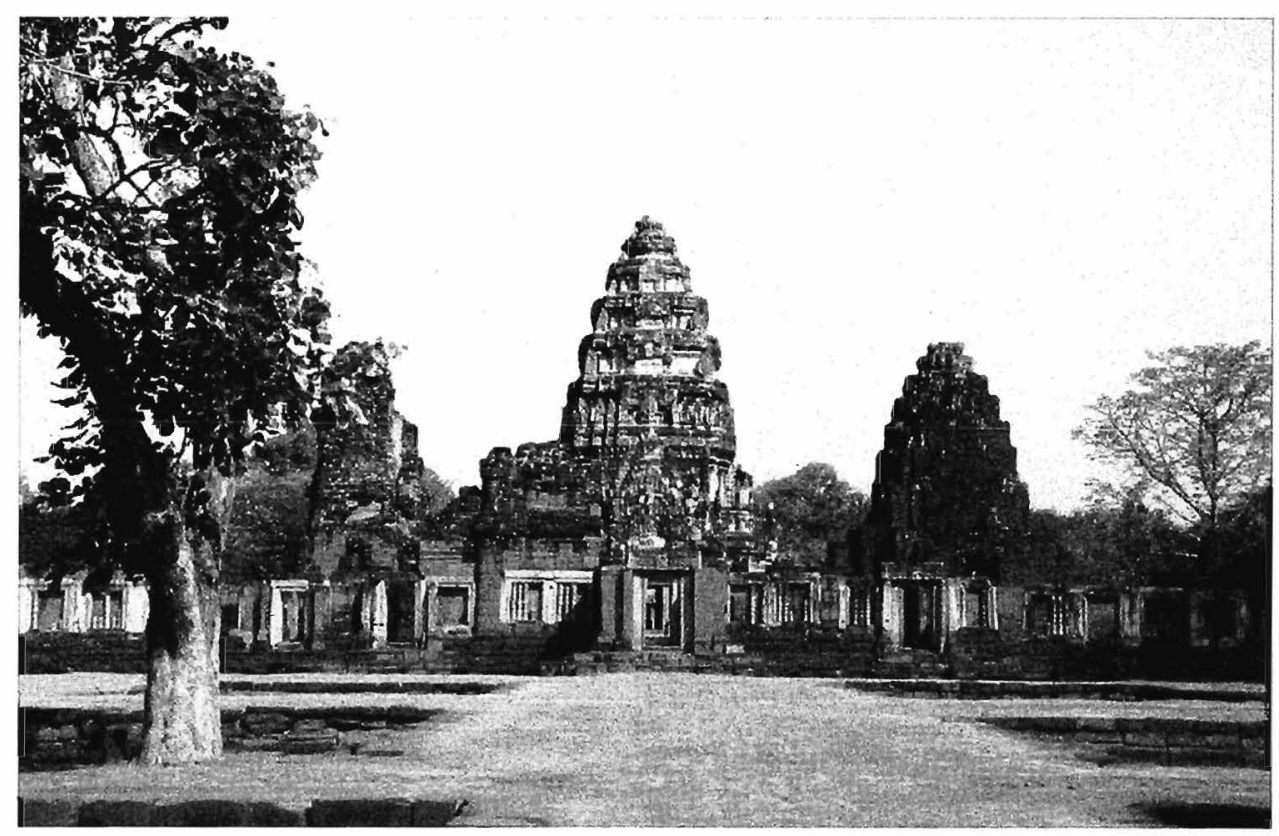

Fig. 2. The Prasat Hin Phimai, northeast Thailand.

Diskul 1979; Glover 1980; Jacques 1979; Mudar 1999; Smith 1979; Vickery 1998), and the Mon-Khmer distinction in Northeast Thailand itself seems something of a false one, at least before A.D. 1000 (Keyes 1974; Siribhadra and Moore 1997:25). Archaeological excavations at prehistoric sites such as Noen U-Loke have also shown that independent local communities were increasing in social complexity during the Iron Age (c. 500 B.C.-A.D. 500) (Higham and Thosarat 2000). The volume of prehistoric ceramics and artifacts recovered in earlier excavations at Phimai indicated that it was more than a simple village even in prehistory, perhaps due to its strategic location on the main trade route between the Khorat Plateau and the Chao Phraya Delta (Bronson 1979:327).

The centuries from the end of prehistory to the splendors of Angkor have been described as "the Dark Ages of Isan" (Rogers 1996:51). However, there is evidence that the people of this period shared important new Indian-influenced practices with their neighbors to the west and south, particularly the use of inscriptions and the construction of religious buildings in permanent materials. The inscriptions recording the "exploratory probes" (Vickery 1998:79) of the sixthcentury overlords from the south have already been mentioned, but a number of other inscriptions refer to protohistoric kings, several Buddhist, who ruled in the region (Brown 1996; Higham and Thosarat 1998: 194-195; Jacques 1989).

A succession of brick pre-Angkorian temple sites has been linked to the political consolidation of the Khmer in Cambodia, Sambor Prei Kuk being the most famous (Bénisti 1970; Boisselier 1955, 1966; Jacques 1996; Parmentier 1927; Siribhadra and Moore 1997:26). In contrast, very few Khmer-style temples were built in Thailand before the tenth century (Charernsupkul 1981; Siribhadra and 
Moore 1997:31). For example, the oldest known Khmer structure in Thailand in good condition is the seventh-century A.D. brick and sandstone Prasat Phum Phon (Parmentier 1927:232; Siribhadra and Moore 1997:85). However, at least some later stone temples were built on the sites of earlier brick structures. For example, a series of brick temples underlie the sandstone temple of the Prasat Phanom Rung, and date back to at least the seventh or eighth centuries (Higham and Thosarat 1998:200). Recent excavations at Prasat Phanom Wan revealed prehistoric remains, including Iron Age burials (Buranrak 2000; Higham and Thosarat 1998, fig. 310; Phongdam 1997). During restoration, the monument was dismantled, and a square 160-cm-thick brick structure filled with soil was found just beneath the central tower. The bricks for this foundation may have been removed from an earlier and adjacent brick structure (Thosarat pers. comm.). Previous investigations at the Prasat Hin Phimai also recorded the presence of bricks beneath the central sanctuary (Pichard 1976: pl. X).

Other early buildings in the northeast relate to the Mon-Dvaravati tradition of Buddhist architecture, particularly brick stupas or chedis at sites such as Nakhon Pathom, U-Thong, and Ku Bua in central Thailand. Similar brick architecture in northeast Thailand includes the remains of an $u$ bosoth (monastery) at Kantarawichai (Diskul 1979) and brick religious structures at Ban Prasat (FAD 1992). Dvaravatistyle stupa bases occur at the site of Muang Fa Daet, which is more famous for its large semas, or boundary stones, carved with figurative Buddhist scenes (Boisselier 1972; Diskul 1956). While nonfigurative sema appear as early as the seventh century, the pictorial semas date to the ninth and perhaps as late as the eleventh century (Brown 1996; Krairiksh 1974:57). Muang Sema is another particularly important Dvaravati site in the northeast, with a large reclining sandstone Buddha figure, dharmacakra ("wheel-of-the-law"), and many brick structures and semas. Recent excavations at Muang Sema recovered a Dvaravati cultural layer some $100-\mathrm{cm}$ thick between layers containing Iron Age and Khmer ceramics (Thosarat pers. comm.).

\section{THE 1998 PRASAT HIN PHIMAI EXCAVATION}

The Origins of Angkor Project (hereafter OAP) is a joint project of the Anthropology Department of the University of Otago, New Zealand, and the Royal Thai Fine Arts Department. It has investigated a number of prehistoric sites in the region, including the Bronze Age cemetery of Ban Lum Khao and the Iron Age sites of Non Muang Kao and Noen U-Loke (Boyd et al. 1999; Habberfield-Short 1999; Higham and Thosarat 1998, 2000; O’Reilly 1999; Rivett 1999). In 1998, the OAP conducted an excavation at the Prasat Hin Phimai to investigate the underlying sequence and examine the brick structure previously reported in more detail. Most previous work at the Prasat concentrated on restoration, although some excavation was done within the temple compound (Table 1).

On 5 January 1998, a 4-by-7-m unit was laid out along the axis of the Prasat, just to the west of the central sanctuary (garbhagra) and $1 \mathrm{~m}$ south of a square excavated in 1997 by Chutima Janthed (n.d.). The datum was set on the corner of the bottom step of the west entrance to the sanctuary, approximately $0.3 \mathrm{~m}$ above the surface of the ground. Temple construction during the Angkorian period involved the deliberate deposition of layers of fill, which can clearly be seen in the stratigraphy of the site (Figs. 3, 4) (cf. Nakao 1992: fig. 2; Pichard 1976). As a re- 
Table i. Previous Investigations at Prasat Hin Phimai

\begin{tabular}{|c|c|c|c|c|}
\hline $\mathrm{BY}$ & TYPE & SITE & REFERENCED & NOTES \\
\hline Early researchers & $\begin{array}{l}\text { Description and } \\
\text { translation }\end{array}$ & Temple compound & $\begin{array}{l}\text { Mouhot 1992; Aymonier } \\
\text { 1901; McCarthy 1994; } \\
\text { Lajonquiére 1912; } \\
\text { Seidenfaden 1922; } \\
\text { Coedès } 1924\end{array}$ & $\begin{array}{l}\text { Henri Mouhot described the Prasat Hin } \\
\text { Phimai in his } 1860-1861 \text { expedition } \\
\text { diary and letters. Aymonier, McCarthy, } \\
\text { Lajonquière, and Seidenfaden surveyed } \\
\text { the area, and Coedès translated the } \\
\text { Prasat's main inscriptions }\end{array}$ \\
\hline FAD in early 1950 s & Restoration & Temple compound & Welch $1985: 130$ & $\begin{array}{l}\text { Restoration of temple compound as tourist } \\
\text { attraction prior to royal visit in } 1954\end{array}$ \\
\hline FAD in 1954,1959 & $\begin{array}{l}\text { Discovery of } \\
\text { inscriptions }\end{array}$ & Temple compound & $\begin{array}{l}\text { Coedès 1964; Welch } \\
\text { 1985:130 }\end{array}$ & $\begin{array}{l}\text { Discovery of two inscriptions dating to } \\
1041 \text { A.D. }\end{array}$ \\
\hline $\begin{array}{l}\text { UNESCO and FAD } \\
1963-1968\end{array}$ & Restoration & Temple compound & Groslier 1976; Pichard 1976 & $\begin{array}{l}\text { Restoration of main sanctuary, survey of } \\
\text { town and temple }\end{array}$ \\
\hline $\begin{array}{l}\text { UNESCO and FAD } \\
1963-1968\end{array}$ & $\begin{array}{l}\text { Discovery of } \\
\text { inscriptions }\end{array}$ & Temple gallery & $\begin{array}{l}\text { Jacques 1969; Welch } \\
\text { 1985:132 }\end{array}$ & $\begin{array}{l}\text { Inscription fragments found in the } \\
\text { southeast corner of the first gallery }\end{array}$ \\
\hline $\begin{array}{l}\text { UNESCO and FAD } \\
1963-1968\end{array}$ & Excavations & Temple compound & Welch 1985:130 & $\begin{array}{l}\text { Excavations at several locations within the } \\
\text { temple compound }\end{array}$ \\
\hline FAD late $1964-1965$ & Excavation & $\begin{array}{l}\text { Below central } \\
\text { sanctuary }\end{array}$ & $\begin{array}{l}\text { Welch 1985:130; Solheim } \\
\text { 1970:49; Bronson } \\
\text { 1979:327 }\end{array}$ & $\begin{array}{l}\text { Excavation exposed the foundation of } \\
\text { brick structure at } 3 \mathrm{~m} \text { down, and } 3 \mathrm{~m} \\
\text { below this, three high-status burials }\end{array}$ \\
\hline Peacock 1968-1969 & Excavation & Temple compound & $\begin{array}{l}\text { Bronson 1979:327; Welch } \\
\text { 1985:133 }\end{array}$ & $\begin{array}{l}\text { Phimai black pottery, bronze, and iron in } \\
\text { association with inhumation burials }\end{array}$ \\
\hline $\begin{array}{l}\text { Silpakorn University } \\
\quad 1968-1969\end{array}$ & Excavation & Temple compound & $\begin{array}{l}\text { Bronson 1979: 327; Welch } \\
\text { 1985:133 }\end{array}$ & $\begin{array}{l}\text { Peacock and Silpakorn University } \\
\text { excavations took place in the same year }\end{array}$ \\
\hline Bronson 1968-1969 & Ceramic comparison & $\begin{array}{l}\text { Temple excavation } \\
\text { at Peacock }\end{array}$ & $\begin{array}{l}\text { Bronson 1976: 709-712, } \\
\text { 1979:318; Welch } \\
\text { 1985:133 }\end{array}$ & $\begin{array}{l}\text { Structural fill contained ceramic types } \\
\text { almost identical to Chansen phase VI } \\
\text { types dated from the late Dvaravati or } \\
\text { early Lopburi phase }\end{array}$ \\
\hline $\begin{array}{l}\text { Silpakorn University } \\
\quad 1971\end{array}$ & Excavations & Outside inner gallery & Batpatong 2514 (1971) & $\begin{array}{l}5 \mathrm{~m} \times 15 \mathrm{~m} \text { east-west trench to water } \\
\text { table at } 4.5 \mathrm{~m} \text {. Disturbed, Ayuttya } \\
\text { period lintel, glazed earthenware, } \\
\text { Chinese porcelain, Lopburi tiles }\end{array}$ \\
\hline Janthed FAD 1996-1997 & Excavation & $\begin{array}{l}\text { North of gopura, } \\
\text { west of sanctuary }\end{array}$ & Janthed n.d. & $\begin{array}{l}\text { Gopura: thick sand layers above water } \\
\text { table. Sanctuary: tiles, Khmer pottery, } \\
\text { gold object, and thick band of rice- } \\
\text { tempered clay bricks }\end{array}$ \\
\hline
\end{tabular}




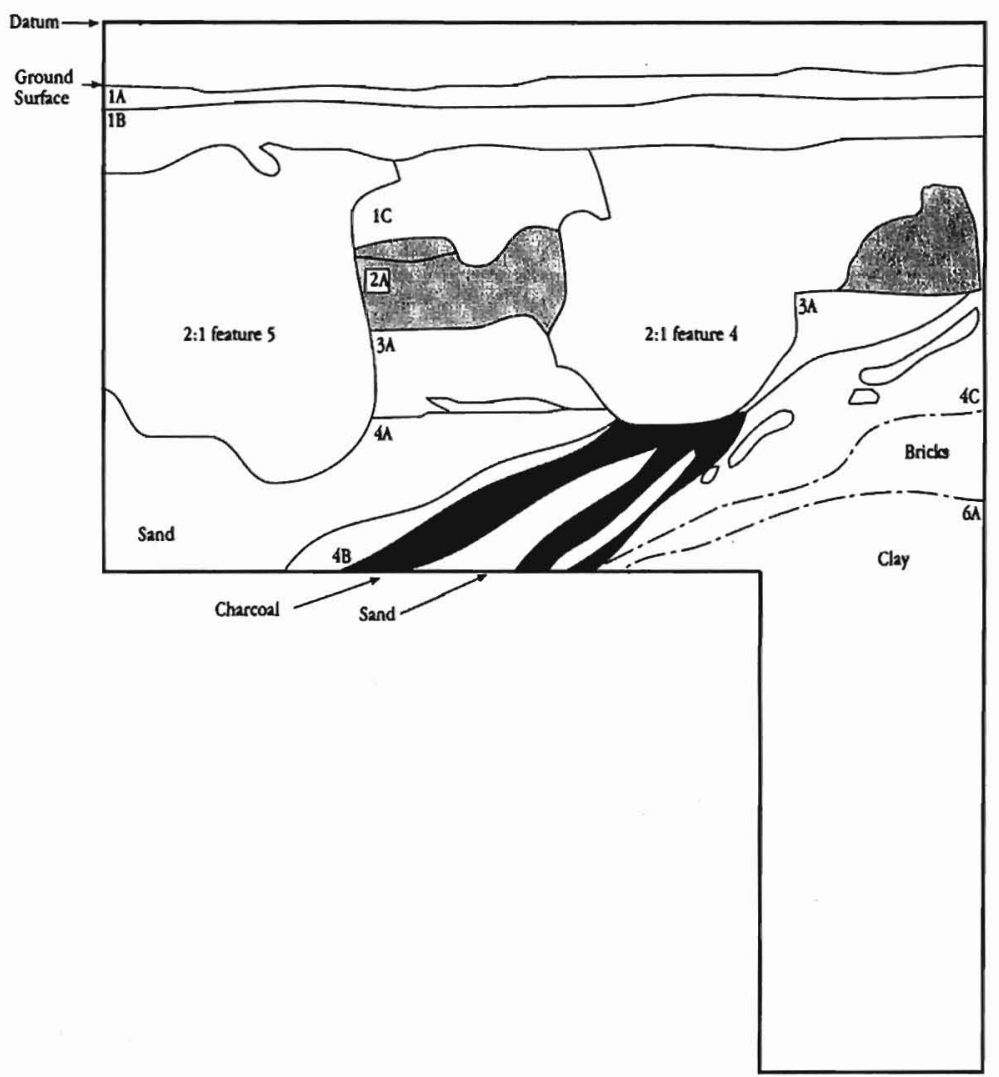

$4 \mathrm{~m}$

Fig. 3. The north section of the 1998 excavation showing layers of sand and charcoal associated with construction of the temple. Key: 1A, pale yellow, $2.5 \mathrm{yr} 8 / 4$, disturbed; $1 \mathrm{~B}$, dark grayish brown, $2.5 \mathrm{yr} 4 / 2$, includes pit contents; $1 \mathrm{C}$, pale red, $7.5 \mathrm{yr} 5 / 4$, includes fragments of red sandstone; $2 \mathrm{~A}$, reddish yellow, $7.5 \mathrm{yr} 7 / 6$, coarse sand, very disturbed in places; $3 \mathrm{~A}$, brown, $10 \mathrm{yr} 5 / 3$, silty, sandy clay, includes many potsherds; $4 \mathrm{~A}$, very pale brown, $10 \mathrm{yr} 8 / 3$, sand, includes clumps of pale gray clay; $4 \mathrm{~B}$, pale brown, $10 \mathrm{yr} 6 / 3$, sand; $4 \mathrm{C}$, strong brown, $7.5 y \mathrm{y} 5 / 8$, sand; $6 \mathrm{~A}$, dark grayish brown, $2.5 \mathrm{yr} 4 / 2$, clay, increasingly sandy toward bottom.

sult, stratigraphy was complex, with much disturbance and redeposition, although major depositional events were marked. Samples were taken by the OAP for more detailed geomorphological analysis. The following section describes the stratigraphy.

Layer One. This was a dark, mottled, and disturbed layer. Red sandstone pieces and eroded laterite lenses probably resulted from construction of the two late twelfth-century A.D. towers nearby. The layer contained bronze fragments, Chinese blue-on-white porcelain, animal bone, a small gold ritual plaque, "olivebrown" (Munsell $2.54 / 3$ ) glazed Khmer ceramics, and a ballalee (lotus-bud ceramic roof decoration) (Talbot $2001: 116)$. In recent times, the area was cleared during restoration. 


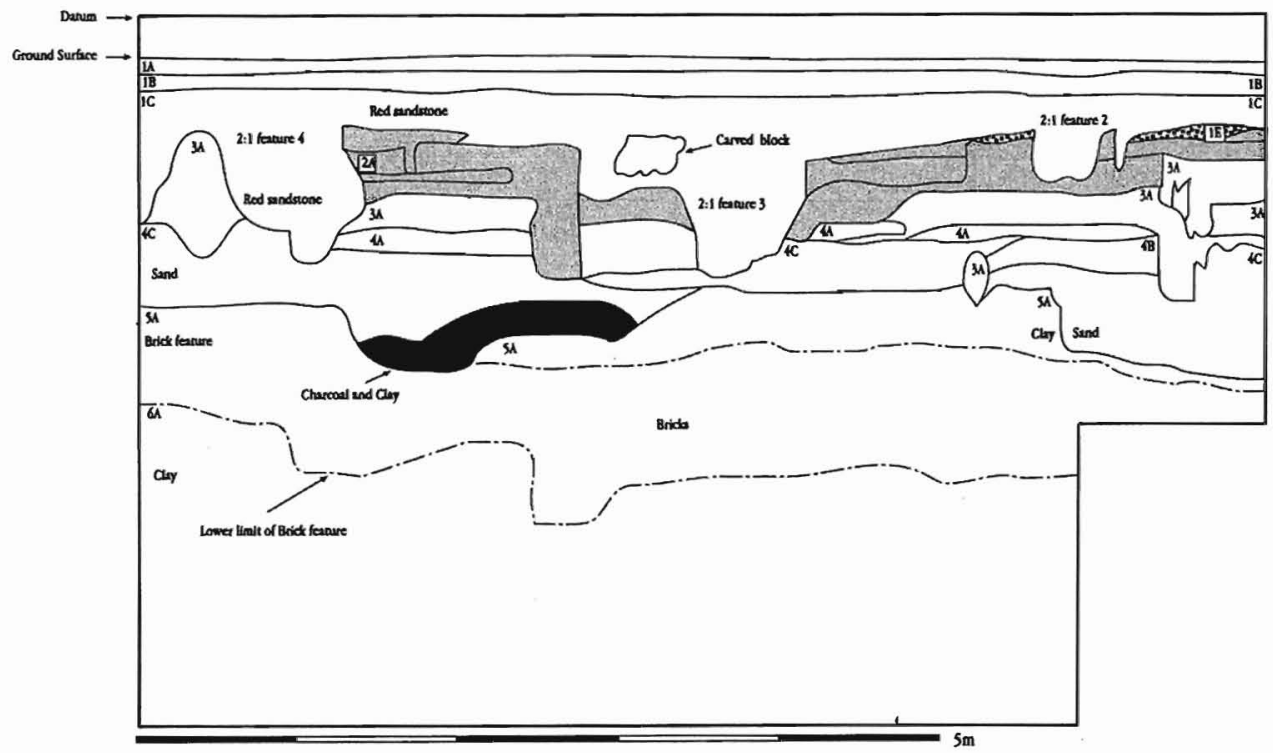

Fig. 4. The east section of the 1998 excavation showing the brick feature. Key: 1A, pale yellow, $2.5 \mathrm{yr} 8 / 4$, disturbed; $1 \mathrm{~B}$, dark grayish brown, $2.5 \mathrm{yr} 4 / 2$, includes pit contents; $1 \mathrm{C}$, pale red, $7.5 \mathrm{yr} 5 /$ 4 , includes fragments of red sandstone; $2 \mathrm{~A}$, reddish yellow, $7.5 \mathrm{yr} 7 / 6$, coarse sand, very disturbed in places; 3A, brown, $10 y r 5 / 3$, silty, sandy clay, includes many potsherds; $4 \mathrm{~A}$, very pale brown, 10yr $8 /$ 3 , sand, includes clumps of pale gray clay; $4 \mathrm{~B}$, pale brown, $10 \mathrm{yr} 6 / 3$, sand; $4 \mathrm{C}$, strong brown, $7.5 \mathrm{yr}$ $5 / 8$, sand; $5 \mathrm{~A}$, red, $2.5 \mathrm{yr} 5 / 8-2.5 \mathrm{yr} 6 / 8$, bricks in dark grayish brown, $2.5 \mathrm{yr} 4 / 2$, clay; $6 \mathrm{~A}$, dark grayish brown, $2.5 y r 4 / 2$, clay, increasingly sandy towards bottom.

Layer Two. This layer of coarse, soft sand was mixed and disturbed, particularly on the side closest to the temple. It seems that riverine sand was collected and deposited, as a single event, apparently to level the ground and perhaps provide drainage during the monsoon. Layers of compacted sand were also described in Pichard's (1976) report on the reconstruction of the temple. The sand contained fragments of roof tile (Talbot 2001:115-116), bronze, white porcelain, and pottery. Several large ill-defined features extending from above contained Angkorian ceramics, roof tiles, small sandstone fragments, a few worn sherds, and fill similar to Layer One.

Layer Three. Beneath the sand lay dark silty and sandy clay typical of the region's flood plain. The surface sloped down approximately $0.2 \mathrm{~m}$ from the northeast over the width of the excavation. Shallow areas of charcoal and a series of postholes were visible. Layer Three produced more ceramic material than all other layers combined, and roof tiles, animal bone, an orange glass bead, a metal spout, and iron slag were also recovered.

Layer Four. This layer comprised a thick deposit of sand, regularly interspersed with charcoal layers. While the top surface of the sand was level, the bottom surface sloped steeply down from the east. This layer lay just above the water table and as the sand became increasingly damp during the excavation, a 1-m secondary baulk was left along the west and south to preserve the walls. Use of a bore indicated that the sand below was at least 2-m thick along the western (unexcavated) side of the unit. Most of the (very little) cultural material from Layer Four was 
found within the charcoal deposits. The same charcoal layers were also found in the 1997 excavation, only $1 \mathrm{~m}$ to the north. A charcoal sample from that excavation was radiocarbon dated and calibrated at the University of Waikato to A.D. 966-1020 (1-sigma). Given the possibilities of inbuilt age, this date is appropriate, considering that the initial construction of the Prasat Hin Phimai temple is thought to have taken place during the reign of Jayavarman VI (A.D. 1080-1107) (Jacques 1996:149).

Layer Five. Beneath the sand layer, along the eastern baulk, lay naturally deposited clay over 3-m thick. Embedded at the top was a thick sloping feature of haphazardly arranged bricks and brick fragments (Fig. 5). Few ceramic sherds were recovered. There was evidence for burning in the dark charcoal-rich clay directly above the bricks. This feature is presumed to be part of the brick structure previously reported to lie beneath the central sanctuary (Pichard 1976: pl. X; Solheim 1970). Pichard (1976:22) described it as a square sump (un puisard carré), which was concentric to the tower but on a slightly different axis. According to Pichard (1976) its sloping internal walls each measured $3.60 \mathrm{~m}$ across at the top

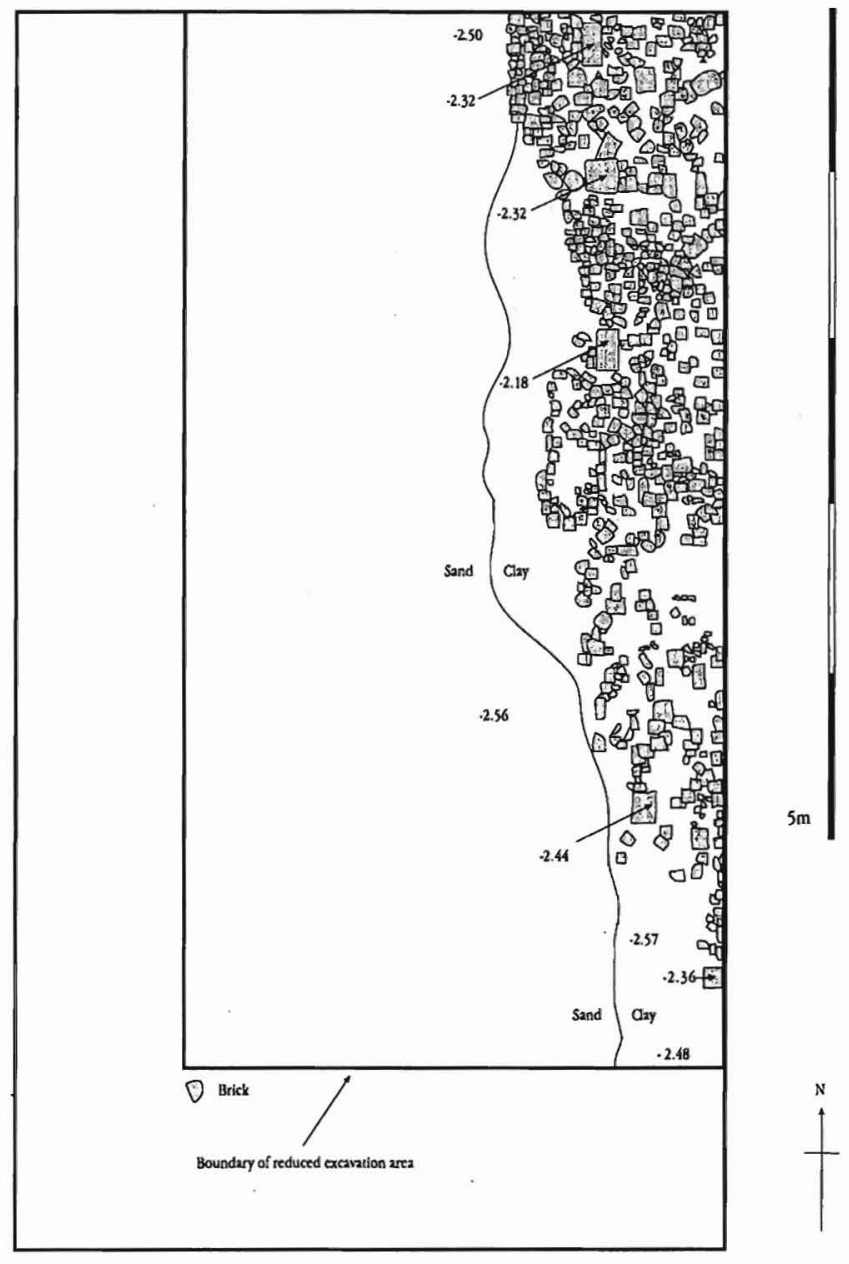

Fig. 5. Plan of the brick feature uncovered during the 1998 excavation. 
and were constructed of bricks of variable size, averaging 7 by 17 by $32 \mathrm{~cm}$. This structure resembled that found beneath the central sanctuary at nearby Prasat Phanom Wan (Buranrak 2000).

Layer Six. This layer of clay extended down to the bottom of the excavation. Below the brick feature, the water table was reached and due to the need to pump water, excavation was limited to a 1-m trench along the eastern wall, beneath the bricks and close to the sanctuary. Water flowed through the sandy lower levels of clay extremely rapidly. Many eroded prehistoric sherds were found, forming a link to Iron Age occupation at sites such as Noen U-Loke. Excavation continued to $4.70 \mathrm{~m}$ below datum when the eastern baulk began to collapse and the excavation was halted on 25 February 1998. At this point completion was already being considered, as the deposit had become increasingly sandy, with natural laterite nodules and few sherds.

\section{BRICKS FROM THE PRASAT HIN PHIMAI EXCAVATION}

A total of $230 \mathrm{~kg}$ of bricks was recovered during the 1998 excavation, all, with few exceptions, from the brick feature in Layer 5. The "red" (Munsell 2.5yr 5/8$2.5 y \times 6 / 8$ ) bricks were heavily rice-tempered with occasional laterite or even potsherd inclusions, unevenly surfaced, and not especially durable. Only eleven were recovered in which a measurement could be made of the original length, breadth, and width. The bricks were roughly square, with lengths and breadths within $3 \mathrm{~cm}$ for over half. The majority measured $7 \mathrm{~cm}$ in thickness, with a range of $6-8 \mathrm{~cm}$. Most had a length of $18-25 \mathrm{~cm}$, with four measuring $22 \mathrm{~cm}$. Average dimensions were 7.8 by 17.3 by $20.8 \mathrm{~cm}$ and a single brick weighed up to $5 \mathrm{~kg}$.

Twenty-nine otherwise indistinguishable bricks were patterned on one of the large faces with two sets of two or three straight diagonal grooves crossing at the center (Fig. 6). One fragment had a curved set of lines and three had parallel lines

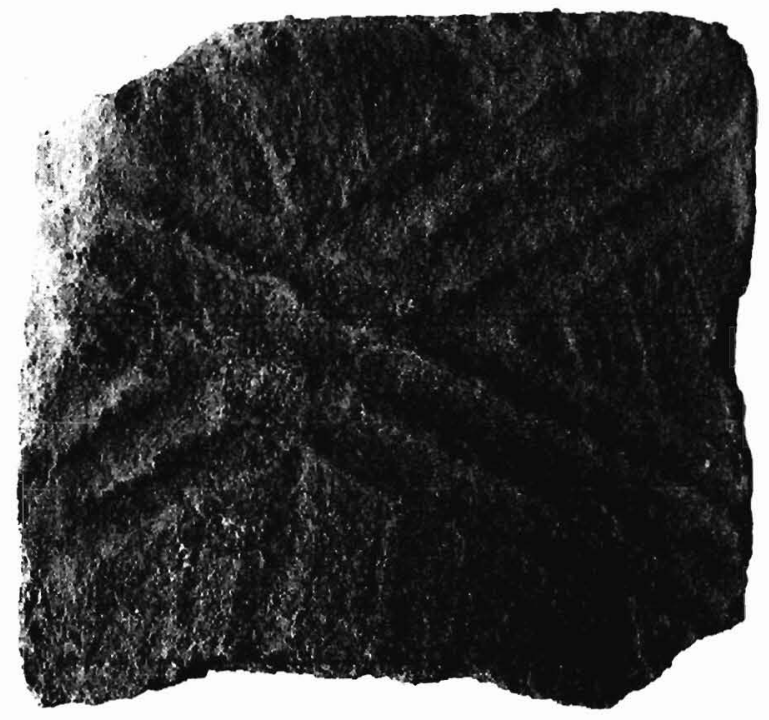

Fig. 6. Brick marked with diagonal finger marks (Cat. 155) (7 by 15 by $16 \mathrm{~cm})$. 
near the edge. The grooves were made before firing and appear to be finger marks. Such bricks were randomly distributed throughout the feature.

In Myanmar, similar finger-marked bricks were part of a cultural tradition coinciding with the construction of Mon and Pyu walled cities in the early centuries A.D. - "... the finger-strokes marking the ancient bricks remain[ing] as a surprisingly intimate record of a long ago human gesture" (Aung Myint and Moore 1991:101; Aung Thaw 1968: fig. 8). Such finger-marked bricks were found at Thaton, where semas similar to those found in the northeast of Thailand indicate contact between the two regions in the late first millennium A.D. (Aung Myint and Moore 1991:93).

This distinctive patterning has also been found on bricks from structures at Dvaravati sites in central and southeast Thailand. At U-Thong, such bricks were found at a chedi (Site No. 15), whose stucco ornamentation recalls that of ninthcentury Khmer art (Kulen and Preah Ko styles), and at a mandapa (Site No. 21), which apparently originally had a roof reminiscent of the pre-Angkorian temple of Kuk Preah Theat (Boisselier 1972:32-33; Parmentier 1927:197). Similar bricks were also found at Chedi Wat Khlong at Ku Bua (Site No. 18) (Boisselier 1972:33, figs. 40 and 41) and at the site of Si Mahosot (Pisnupong 1992, 1993). The finger-marked patterns were not in themselves decorative but aided the adherence of a wet clay mortar, and have been used to date religious brick structures to about the end of the eighth century A.D. (Boisselier 1972:32-33).

Other evidence also suggests that the Prasat Hin Phimai was built at a site that had been sacred for some time. Early last century, a Dvaravati style dharmacakra ("wheel-of-the-law") and Buddha image were found together at the temple (Siribhadra and Moore $1997: 229$ ). Carved on a stone re-used as a doorjamb in the temple wall is an eighth-century inscription (K.1000) describing a Buddhist king called Sauryavarman (Saurya = valour, might), and a stele carved with homages to both Shiva and the Buddha dates to the same period (Jacques 1989:19, 1996: 149). In a similar fashion to Prasat Phanom Wan, the bricks recovered at Prasat Hin Phimai were apparently reused from an earlier structure (Buranrak 2000; Thosarat pers. comm.). The period of the seventh to ninth centuries is an appropriate date for the Prasat Hin Phimai bricks, considering the radiocarbon date obtained from the overlying charcoal (966-1020 A.D., plus inbuilt age).

\section{THE CERAMIC SEQUENCE AT THE PRASAT HIN PHIMAI}

Just over $50 \mathrm{~kg}$ of potsherds were recovered from the 1998 excavation, with Layer Three containing over 70 percent (by weight) of all sherds at the site. Many deposits were mixed, and redeposited prehistoric sherds were found in all layers. However, despite the fragmented nature of the assemblage and the mixed nature of the deposits, ceramic analysis distinguished some diachronic trends.

Phimai Phase One (Layer Six). Dense deposits of redeposited Iron Age sherds suggest that the site of the Prasat Hin Phimai was indeed important in prehistoric times. Comparison with the existing ceramic sequence in the region (Welch and McNeill 1988-1989), suggests that while the site appears to have been occupied by the mid-first millennium B.C., the main prehistoric ceramic assemblage dates to the late first millennium B.C. and the early centuries A.D. The earliest, red-slipped, sherds probably belong to the Prasat phase (c. 600-200 B.C.). However, most 

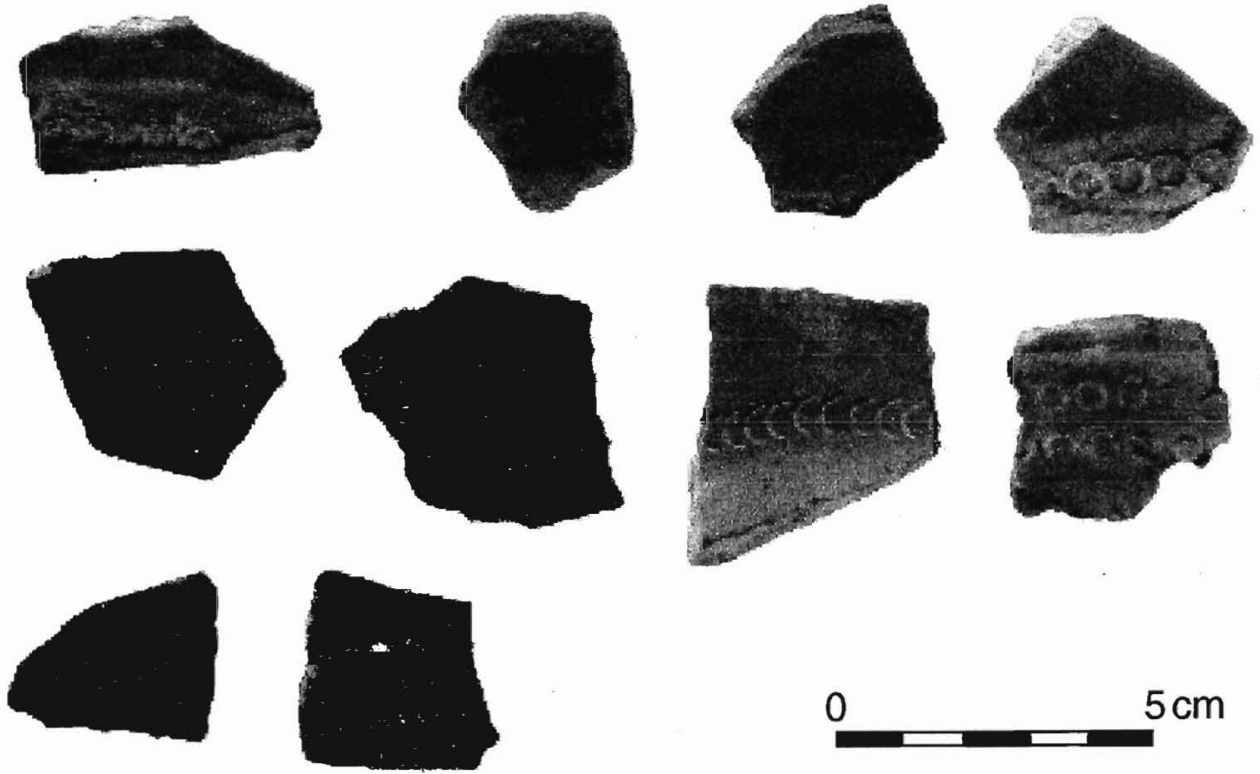

Fig. 7. Incised Phimai Black sherds from the 1998 excavation.

sherds appear to belong to the Classic Phimai phase (c. 200 B.C.-A.D. 300), including "Thick-Fiber-Tempered Earthenware" and the best-known ware in the region, Phimai Black (Solheim and Ayres 1979; Welch and McNeill 19881989). The most unusual characteristics of this pottery are its reduced firing and incised decoration (Solheim 1965; Solheim and Ayres 1979) (Fig. 7).

Phimai Black is a regional ceramic tradition, distributed throughout the upper Mun River Valley, found in abundance at Phimai and sites such as Noen U-Loke, and as far away as Ban Krabuang (33 km northeast), Nakhon Ratchasima city (50 $\mathrm{km}$ southwest), and Ban Thamen Chai (40 km southeast) (Welch 1989:20). Similarities in size, shape, color, rim form, and decoration have suggested semiindustrial mass production, perhaps at Phimai itself (Welch 1989:20). Two interesting exceptions to this ware's regional distribution were the discovery of sherds at Chansen, a Dvaravati site in central Thailand (Bronson and Dales 1972), and at Si Mahosot, the Dvaravati site in southeast Thailand where finger-marked bricks were also recovered (Pisnupong 1992).

Phimai Phase Two. This phase is represented by the Layer 5 bricks, albeit not the entire layer, which instead dates to the period of the construction of the Prasat. Although the original ceramic context of the bricks is uncertain due to their reuse, it is possible that they were originally associated with certain eroded and possibly redeposited sherds recovered that were reminiscent of ceramics at Dvaravati sites such as Chansen (Bronson 1976) and Muang Fa Daet (Indrawooth 1985; Indrawooth and Narkwake 1991:110). In particular, cord-marked and incised sherds (Bronson 1976:142; cf. Indrawooth 1985: fig. 22), some from carinated pots (cf. Indrawooth 1985: fig. 5, 1991:110), were recovered in Layer Three and below. 
Phimai Phase Three (Layers Five, Four, Three, Two, and One). This phase relates to construction and ongoing activity at the Angkorian temple. Ceramics from these layers clearly belonged to a wider cultural context than before, in that wheel-formed, sand-tempered pan-regional ceramics appeared for the first time. From Layer Five, at least some sherds had a more standardized manufacture and clearly belonged to a quite different technical and stylistic tradition than the chafftempered ceramics typical of the Iron Age (see also Welch and McNeill 19881989: 120).

The earliest of these sherds were fired pink (Munsell 5yr 8/3-5yr 8/4) or orange (2.5yr 7/3-2.5yr 7/8) in an oxidizing atmosphere at a relatively high temperature. They were hard, thin, wheel formed, and even, and many were decorated with two or three shallow incised lines on the shoulder. Similar sherds have been recovered from kilns at Ban Kruat in Buriram province (Chandavij 1990: pl. 14). Rims closely resemble "Le" wares from Chansen phase VI (850/950-1100/1200 C.E.) (Bronson 1976; Bronson and Dales 1972), particularly those sherds with grooves (cf. Indrawooth 1985: fig. 6). From Layer Three on, Khmer glazed stonewares, and from Layer Two on, Chinese porcelain sherds were recovered. Although little information is available on unglazed Khmer ceramics (Chandavij 1990; Rooney 1984), the "Le" sherds do appear at the site well before those of the typical glazed Khmer stonewares, which were probably produced at the Buriram kilns from around the tenth century (Brown 1988:46; Chandavij 1990:241; FAD 1989). Typical brown-glazed Khmer sherds were also absent from Chansen (Bronson 1976:709). Ceramic function may be partly responsible for the temporal distribution at Prasat Hin Phimai, as unglazed wares seem to have been associated with early construction of the temple, while glazed stonewares and porcelains were an important part of ongoing ritual.

\section{CONCLUSION}

The importance of religious architecture to the empire of Angkor is difficult to overstate. It is even emphasized on the temples themselves. For example, at the Prasat Hin Phimai, one pediment features an image of the sanctuary itself (Siribhadra and Moore $1997: 249)$.

The dominance of these Angkorian temples on the modern landscape can overshadow the complex architectural histories of their sites, particularly in light of the ongoing tradition of rebuilding in various styles at the same sacred location. Sites such as Muang Sema, which were abandoned for many centuries up to the present day, can often provide archaeologists with more information about the protohistoric period than reconstructed and continuously occupied sites like the Prasat Hin Phimai.

While Muang Sema was a more important site than Phimai during protohistoric times (Thosarat pers. comm.), this was not the case in the later Angkorian period, when Phimai was a major regional center. Jayavarman VI's successful bid for the throne at Angkor may have given him reason and opportunity to tear down the old brick temple of his ancestors and replace it with the existing sandstone temple (Higham and Thosarat 1998:198). The 1998 excavation suggests that part of such reconstruction was the reuse of bricks from an earlier structure to 
form the new foundations. Such rebuilding and reuse, while not always convenient for archaeologists, is clearly an important indication of the changing power dynamics of local dynasties, in this case that of Mahidarapura.

In conclusion, the Prasat Hin Phimai was an important Angkorian center, but one built quite literally on an earlier foundation. By the late first millennium A.D., the independent Iron Age communities evidenced at sites such as Noen U-Loke had been transformed into protohistoric "kingdoms" that were part of a complex panregional landscape of shared cultural traits. Beneath the Prasat Hin Phimai lies material evidence of these people, and the site should be added to the list of their architectural remains.

\section{ACKNOWLEDGMENTS}

We would like to express our sincere thanks to Charles Higham and Rachanie Thosarat, the co-directors of the Origins of Angkor Project, for their support and for their suggestions on this paper. We would like to express our gratitude to the Royal Thai Fine Arts Department and the staff of the Prasat Hin Phimai Historic Park. We are also grateful to Wilhelm Solheim II for his comments, Elizabeth Moore for her advice on the finger-marked bricks from Myanmar, Bill Boyd and Jeremy Habberfield-Short for their help concerning the geomorphology of the site, Morag McCaw for the faunal identifications, Bec Connelly for advice on the iron artifacts, Nigel Chang and Les O'Neill for their assistance with the artifact photography, Judy Volker and Paul Rivett for their assistance in Phimai, and, indeed, all those who worked on the excavation or assisted with Phimai '98. The excavation was funded by a NZASIA/ASIA 2000 Research Fund Scholarship, the Marsden Fund, and Earthwatch and its Research Corps.

\section{REFERENCES CITED}

Aung Myint, AND E. MOORE

1991 Finger-marked designs on ancient bricks in Myanmar. Journal of the Siam Society (79):81103.

Aung Thaw

1968 Report on the Excavations at Beikthano. Rangoon: Revolutionary Government of the Union of Burma Ministry of Union Culture.

AYMONIER, E.

1901 Le Cambodge II Les Provinces Siamoises. Vol. 2. Paris: Ernst Leroux.

BATPATONG, K.

2514 (1971) Report on Excavations at Prasat Hin Phimai by Kongdet Batpatong and Silpakorn University. Bangkok: Fine Arts Department. (In Thai.)

BÉNISTI, M.

1970 Rapports entre le premier art. Khmer et l'art Indien. Mémoire Archéologique V. Paris: Publications de École Française d'Extrême-Orient.

BOISSElier, J.

1955 La Statuaire Khmère et son Évolution. Saigon: Publications de l'École Française d'Extrême Orient.

1966 Le Cambodge. Manuel d'Archaeologie d'Extreme-Orient Asie du Sud-Est 1. Paris: Editions A. et J. Picard et Cie.

1972 Travaux de la mission archéologique Française en Thailande. Arts Asiatiques 25:27-90.

Boyd, W., C.F.W. Higham, and R. MCGRath

1999 The geoarchaeology of the Iron Age "moated" sites of the upper Mae Nam Mun Valley, NE Thailand. I: Palaeodrainage, site-landscape relationships and the origins of the "moats." Geoarchaeology: An International Journal 14(7):675-716. 
BRIGGs, L.

1951 The ancient Khmer empire. Transactions of the American Philosophical Society 4(1):1-295.

BRONSON, B.

1976 Excavations at Chansen and the Cultural Chronology of Protohistoric Central Thailand. Ph.D. diss., University of Pennsylvania, Philadelphia. Ann Arbor: University Microfulms.

1979 The late prehistory and early history of central Thailand with special reference to Chansen, in Early South East Asia: 315-336, ed. R. Smith and W. Watson. Oxford: Oxford University Press.

Bronson, B., and G. Dales

1972 Excavations at Chansen, Thailand, 1968, 1969: A preliminary report. Asian Perspectives 15: 15-46.

BROWN, ROBERT

1996 The Dvaravati Wheels of the Law and the Indianization of South East Asia. Leiden: E. J. Brill.

BROWN, ROXANNA

1988 The Ceramics of South-East Asia: Their Dating and Identification. Singapore: Oxford University Press.

BURANRAK

2000 Report on the restoration of Prasat Hin Phnom Wan. Tambon Ban Pho, Amphoe Muang, Changwa Nakhon Ratchasima. Unpublished report. (In Thai.)

ChandaviJ, $\mathrm{N}$.

1990 Ancient kiln sites in Buriram province, north-eastern Thailand, in Ancient Ceramic Kiln Technology in Asia, ed. Chuimei Ho. Hong Kong: University of Hong Kong.

CharernSUPKUL, A.

1981 The Structure Types and Pattern Bonds of Khmer and Srivijayan Brick Architecture in Thailand. Bangkok. (In Thai.)

CoEdès, G.

1924 Études Cambodgiennes. Bulletin de l'École Française d'Extrême Orient 24:345-358.

1964 Inscriptions du Cambodge 7. Paris: Publications de l'École Française d'Extrême Orient.

Diskul, M.C.S.

1956 Mueng Fa Dæd: Ancient town in northeast Thailand. Artibus Asiae 19:362-367.

1979 The development of Dva-ravati-sculpture and a recent find from northeast Thailand, in Early South East Asia, ed. R. Smith and W. Watson. London: Oxford University Press.

FAD (FINE ARTS DEPARTMENT)

1989 Ancient Kiln Sites in Buriram Province. Bangkok: Fine Arts Department of Thailand.

1992 Ban Prasat; an Archaeological Sile. Bangkok: Fine Arts Department.

FrEEMAN, M.

1996 A Guide to Khmer Temples in Thailand and Laos. Bangkok: River Books.

Glover, I.

1980 Ban don Ta Phet and its relevance to problems in the pre- and protohistory of Thailand.

Bulletin of the Indo-Pacific Prehistory Association 2:16-30.

Groslier, B.

1976 Travaux archeologiques. Travaux et Perspectives de l'Ecole Francaise d'Extreme-Orient. Paris: École Française d'Extrême Orient.

HabBerfield-Short, J.

1999 The geoarchaeological context of two Iron Age sites in northeast Thailand. Archaeology in New Zealand 42(3):213-229.

Hrgham, C.F.W., and R. Thosarat

1998 Prehistoric Thailand from Early Settlement to Sukhothai. Bangkok: River Books.

2000 The origins of the civilisation of Angkor. Antiquity 74(283):27-28.

INDRAWOOTH, P.

1985 Index Pottery of Dvaravati Period. Bangkok: Silpakorn University.

INDRAWOOTH, P., AND P. NARKWAKE

1991 Muang Fa Daed Song Yang: New archaeological evidence. Recentes Recherches en archeologie en Thailand. Bangkok: Silpakorn University. 
JaCQues, C.

1969 Etudes d'epigraphie cambodgienne. Bulletin de l'École Française d'Extrême Orient 56:57-74.

1979 'Funan', 'Zhenla': The reality concealed by these views of Indochina, in Early South East Asia: 371-379, ed. R. Smith and W. Watson. Oxford: Oxford University Press.

1989 The Khmer in Thailand: What the inscriptions inform us. Trans. M. C. Subhardradis Diskul. SPAFA Digest 10(1):16-24.

1996 Angkor: Cities and Temples. Bangkok: River Books.

JANTHED, C.

n.d. Report on the 1997 excavation at the Prasat Hin Phimai. In progress.

Keyes, C.

1974 A note on the ancient towns and cities of northeastern Thailand. Southeast Asia Studies $11(4): 497-506$.

KRAIRIKSh, P.

1974 Semas with scenes from the Mahanipata-jatakas in the National Museum at Khon Kaen. Art and Archaeology in Thailand. Bangkok: Fine Arts Department.

LAJONQUí́re, E. DE LA

1912 Inventaire Descriptif des Monuments du Cambodge. Vol. 2. Paris: Ernst Leroux.

MCCARTHY, J.

1994 (1900) Surveying and Exploring in Siam with Descriptions of Lao Dependencies and of Battles against the Chinese Haws. Bangkok: White Lotus.

Моунот, $\mathrm{H}$.

1992 Travels in Siam, Cambodia and Laos 1858-1860. Singapore: Oxford University Press.

MUDAR, K.

1999 How many Dvaravati kingdoms? Locational analysis of first millennium A.D. moated settlements in central Thailand. Journal of Anthropological Archaeology 18:1-28.

NAKAO, Y.

1992 A summary report on the excavation of Banteay Kdei's front colonnaded hall. Renaissance Culturelle du Cambodge 6. Tokyo: Institute of Asian Cultures, Sophia University.

O'REILLY, D.

1999 A Diachronic Analysis of Social Organisation in the Mun River Valley. Ph.D. diss., University of Otago, New Zealand.

Parmentier, $\mathrm{H}$.

1927 L'art Khmer Primitif. Paris: École Française d'Extrême-Orient.

Phongdam, B.

1997 Report on excavations at Prasat Phanom Wan. Muang Boran 23(3):95-108. (In Thai.)

Pichard, P.

1976 Pimay Etude Architecturale du Temple. Paris: École Française d'Extrême-Orient.

PISNUPONG, P.

1992 History and Archaeology of Muang Si Mahosot. Bangkok: Fine Arts Department. (In Thai.)

1993 History and Archaeology of Muang Si Mahosot 2. Bangkok: Fine Arts Department. (In Thai.)

Quaritch Wales, H. G.

1969 Dvaravati-The Earliest Kingdom of Siam. London: Bernard Quaritich.

RivetT, P.

1999 Community Landscapes in Northeast Thailand. M.A. thesis, University of Otago, New Zealand.

ROGERS, P.

1996 Northeast Thailand from Prehistoric to Modern Times. Bangkok: DK Books.

ROONEY, D.

1984 Khmer Ceramics. Singapore: Oxford University Press.

SeIdenfaden, E.

1922 Complement a l'inventaire descriptif des monuments du Cambodge pour les quartre provinces du Siam occidental. Bulletin de l'École Française d'Extrême-Orient 22:55-100. 
SiribHadra, S., AND E. MOORE

1997 Palaces of the Gods Khmer Art and Architecture in Thailand. Bangkok: River Books.

SMITH, R.

1979 Mainland Southeast Asia in the seventh and eighth centuries, in Early South East Asia: 443-456, ed. R. Smith and W. Watson. Oxford: Oxford University Press.

SOLHEIM, W. II

1965 A preliminary report on a new pottery complex in northeastern Thailand. Siam Society Felicitation Volumes of Southeast Asian Studies 2:249-261.

1970 Northern Thailand, Southeast Asia, and world prehistory. Asian Perspectives 13:145-162.

Solmerm, W. II, And M. Ayres

1979 The late prehistoric and early historic pottery of the Khorat Plateau, with special reference to Phimai, in Early South East Asia: 249-254, ed. R. Smith and W. Watson. Oxford: Oxford University Press.

TALBOT, S.

2001 Angkorian architectural ceramics from a Khmer temple in northeast Thailand. Bulletin of the Indo-Pacific Prehistory Association $21: 114-118$.

VICKERY, M.

1998 Society, Economics, and Politics in Pre-Angkor Cambodia. The 7th-8th Centuries. Tokyo: The Center for East Asian Cultural Studies for UNESCO, The Toyo Bunko.

WeLCh, D.

1985 Adaption to Environmental Unpredictability: Intensive Agriculture and Regional Exchange at Late Prehistoric Centers in the Phimai Region, Thailand. Ph.D. diss., University of Hawai'i, Honolulu.

1989 Late prehistoric and early historic exchange patterns in the Phimai Region, Thailand. Journal of Southeast Asian Studies 20(1):11-26.

WelCh, D., AND J. MCNerLL

1988- Excavations at Ban Tamyae and Non Ban Kham, Phimai region, northeast Thailand. 1989 Asian Perspectives 28:99-123.

\section{ABSTRACT}

Northeast Thailand (Isan) was incorporated into the polity of Angkor around the end of the first millennium A.D. Well before this time, local communities in the Phimai region had adopted important activities such as the use of inscriptions and the construction of religious architecture in permanent materials. In 1998, the Origins of Angkor Project undertook an archaeological excavation at the most important Khmer temple in Thailand, the Prasat Hin Phimai. The excavation recovered late prehistoric ceramics and remains of an early brick structure, probably religious in nature, which had been re-used as part of the foundation of the sandstone Angkorian temple. Keywords: Angkor, Phimai, Mun River, Thailand, Isan, prehistoric, architecture. 